\title{
Boneless Maxillary Reconstruction
}

\section{Kemiksiz Maksilla Rekonstrüksiyonu}

(1) Osman KELAHMETOĞLU1, ib Ethem GÜNEREN1, id İsmail Melih KUZU², id Kemalettin YILDIZ1

${ }^{1}$ Bezmiâlem Vakıf University Fculty of Medicine, Department of Plastic Surgery, İstanbul, Turkey

2State Hospital, Clinic of Plastic Surgery, Zonguldak, Turkey

\section{ABSTRACT}

Objective: Although the midface is supported by maxillary bone, reconstruction of maxillary bony defects does not always require osseous reconstruction. A series of maxillary facial defects of moderate to severe sizes (Brown and Shaw 4-6) uniformly reconstructed with myocutaneous free flaps is presented.

Methods: Retrospective analysis was done for consecutive 10 cases between 2013-18. Seven of the cases had defects caused by oncological resection and 3 defects caused by trauma. Free vertically oriented rectus abdominis (fVRAM) flap was used to reconstruct these defects.

The mean age of patients was 42.9 years (range=20-71 years). All flaps survived and 2 flaps had small skin island problems. Rapid recovery, low morbidity, acceptable oral competency, and satisfactory cosmetic appearance were obtained with the reconstruction using fVRAM flaps.

Conclusion: According to our limited experience, acceptable reconstruction of extensive maxillary defects can be done with using only soft tissue flap, which is versatile and safe.

Keywords: Maxillectomy, midface, rectus abdominis myocutaneous flap, facial defect, soft tissue reconstruction

Level of Evidence: IV

\section{ÖZ}

Amaç: Maksiller kemik orta yüzün iskeletsel desteğini oluşturmakla beraber, kemik doku kullanılmadan da orta yüz rekonstrüksiyonu yapılabilir. Bu amaçla orta yüz bölgesinin orta ila şiddetli boyutlardaki (Brown ve Shaw 4-6) defektlerinde kas deri serbest flebini kullandık

2013-18 yılları arasında ardışık 10 vaka için retrospektif analiz yapıldı. Olguların yedisi onkolojik rezeksiyon, üçü travma nedenli idi. Tüm olgularda serbest vertikal rektus abdominis kas deri flebi kullanıldı

Yöntemler: Hastaların yaş ortalaması 42,9 idi (20-71). İki flepte deri adasında küçük problemler dışında tüm flepler sorunsuz iyileşti. Bu çalışmada, hızlı iyileşme, düşük morbidite, kabul edilebilir oral yetkinlik ve tatmin edici kozmetik görünüm elde edildi

Sonuç: Sınırlı tecrübemize göre, orta yüzün kemik içeren orta-geniş defektlerinde sadece yumuşak doku içeren rekonstrüksiyon kabul edilebilir bir seçenektir.

Anahtar Sözcükler: Maksillektomi, orta yüz, rektus abdominis kas deri flebi, defekt, yumuşak doku onarımı

Kanıt Düzeyi: IV

\section{Introduction}

The maxilla is the most important bony structure of the midface, extending between the zygomatic bone, the orbit, and the upper teeth, which is like a six-walled pyramide. It is vulnerable to midfacial trauma because of the buttresses that extend around the bone and inside there is a sinus contains $2-4 \mathrm{~mL}$ of air. Midfacial tissue losses caused by trauma or oncological resections of skin, soft-tissue, and bone may not be life-threatening, but can have 
serious functional and esthetic consequences $(1,2)$. The complex three-dimensional structure of the region requires careful and specialized reconstruction to obliterate dead space and reestablish the support features.

Bony deficiency can be filled with a bulky soft tissue flap to obliterate the dead space and to provide the competency of the oral cavity without any osseous component. The major aesthetic challenge is the provision of adequate cheek volume to improve the hollow and retracted skin appearance. Reconstruction of palatomaxillectomy defects using only soft tissues were presented and good functional and cosmetic outcomes were reported. This approach is not only a salvage option, but also (in selected cases) a quick, durable, and safe primary reconstructive procedure associated with minimal donor site morbidity and good resistance to the side-effects of later adjuvant radiotherapy (RT) (3).

We presented the use of a free vertical rectus abdominis myocutaneous (fVRAM) flap for reconstruction of Class IV, $\mathrm{V}$, and VI midfacial defects according to the Brown and Shaw (B\&S) classification (4).

\section{Methods}

Retrospective analysis was done for consecutive 10 cases, treated in Bezmialem Vakıf University Hospital, Department of Plastic, Reconstructive and Aesthetic Surgery, between 2013-2018. All patients had class IV, V, or VI midface defects according to the B\&S classification accompanied by large losses of soft tissue and skin. All patients received fVRAM flaps with variable size of skin island. Resection and reconstruction were performed by the same plastic surgery team. Polypropylene mesh was used for donor site closure in all patients

This study was approved by the Bezmialem Vakıf University Hospital Institutional Review Board and all participants signed an informed consent agreement.

\section{Results}

The male:female ratio was 1:1. Seven defects were associated with tumor resection and 3 were secondary to trauma. Three out of 7 oncology patients had squamous cell carcinomas, 2 softtissue sarcomas and 2 basal cell carcinoma. The mean ages of the oncological and trauma patients were 51 (range $=28-71)$ and 24 (20-27) years, respectively. The overall mean age was 42.9 (2071) years. B\&S class VI defects were present in 4 cases, class $V$ defects in 4 , and class IV defects in 2. The mean hospitalization period was 28.7 (14-61) days (Table 1).

One flap skin island was lost on day 6 postoperatively because of neck hyperextension and rupture of the anastomosis during ocular examination. He was a Syrian civil war victim, who was injured by a gunshot. However, some of the muscle bulk remained healthy and the skin defect was reconstructed using a Mustardé cheek flap. In second case, early re-exploration was required at the day after surgery, because of venous congestion of the flap. A hematoma was encountered and although appropriate drainage was done, the skin island was lost. All other flaps survived without any complications (Figures 1,2). No donor site morbidity was seen.

All oncological cases received postoperative RT. Late tumor recurrences developed in two patients with sarcoma who were then threated with adjuvant chemoradiotherapy. Both eyes were

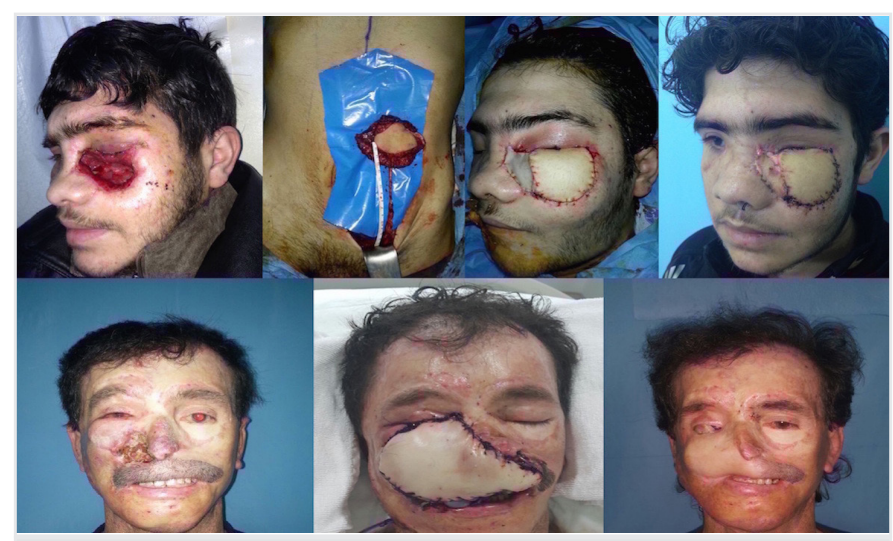

Figure 1. Above are the preoperative, immediate postoperative and postoperative (after 1 month) views of Case 3. Below are the preoperative, early postoperative and postoperative (after 12 months) views of Case 6

Table 1. Patients' demographics, defect sizes, orbital status, hospitalization, follow-ups and flap results

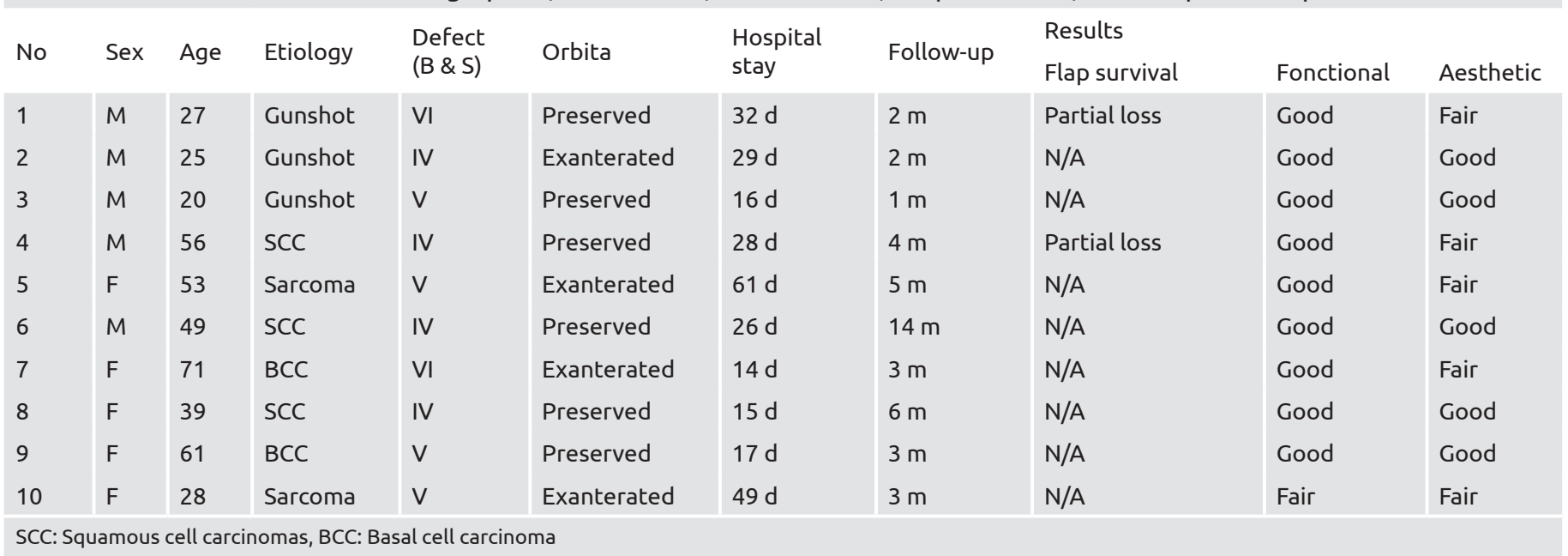




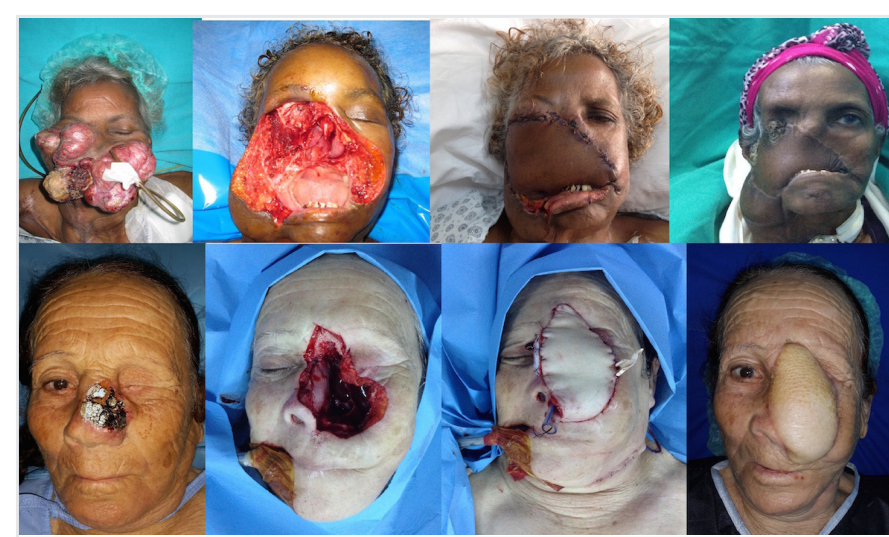

Figure 2. Above are the preoperative, intra-operative, early postoperative and postoperative (after 5 months) views of Case 5. Below are the preoperative, intra-operative, early postoperative and postoperative (after 3 months) views of Case 7

preserved with normal visual function in 6 cases, remaining 4 cases underwent one sided orbital exenteration. Although no dental rehabilitation was done, acceptable aesthetic appearance with oral competency was obtained in all cases.

\section{Discussion}

The midface is one of the most important facial regions, playing major roles in terms of function and appearance. The complex structure of the maxilla must be considered while choosing a method of midface reconstruction (2-6). Osseous reconstruction is not necessary for functional and supportive features (7). Moreover, structural bony repair can be ignored and cavity obliteration using healthy soft tissue may in fact be ideal. The important steps leading to successful midface reconstruction may be counted as proper wound closure, obliteration of the palatomaxillectomy defect, supporting of orbital base (if the globe is preserved), obliteration of the orbital cavity (if the globe is exenterated), provision of a barrier between the anterior cranial fossa and the nasal sinuses, separation of oral-nasal cavities and restoration of the facial contour, respectively.

Extensive midfacial defects are usually caused by high-energy gunshots or major tumor resections. Reconstructions that respect the anatomical extensions and appearance of the midface afford reliable and effective results (8). A large number of pedicled and free flaps have been used by plastic surgeons to reconstruct complex defects (5-7,9-12). Fasciocutaneous flaps may be adequate to repair defects involving minimal soft-tissue loss (8). Osteocutaneous flaps (11,13-15), myocutaneous flaps $(1,4)$, osteomyocutaneous flaps (16-18), or combined flaps $(10,19)$ have been used according to the defect components. We prefer to use boneless soft tissue flaps in all cases.

Massive tumor resection and RT are always associated with long-term risks of complications such as collapse, contraction, entropion/ectropion, and contour irregularities $(1,5,7)$. Adjuvant RT triggers soft-tissue contraction, fibrosis, and osteoradionecrosis. Bulky soft tissue flaps may improve the negative effects of radiation (20). Osteocutaneous flaps afford the best osseous support for future dental reconstruction but adjuvant RT is a factor which complicates outcome and is also associated with a risk of osteoradionecrosis $(1,13,20)$. In high energy gunshot injuries more efforts should be required to find appropriate vessel for free flaps.

However, osteocutaneous flaps yield good esthetic and functional results after maxillary reconstruction, the soft-tissue component of it lacks adequate bulk and the pedicle is not sufficiently long to allow contact with neck vessels in the absence of vein grafting or placement of a flow-through flap, but a boneless soft tissue flap has a long pedicle enables graft anastomosis to the neck vessels without the need for vein grafting or a flow-through flap. Many of our cases underwent adjuvant RT without any sideeffects. Even our follow-up period was not long enough to get late conclusion, it was enough in duration to see the ultimate effects of radiation on the flap. In addition to that, soft-tissue flaps afford simple, rapid, and effective wound-healing.

Large muscle flaps, such as rectus abdominis (RA) and latissimus dorsi (LD) are used to reconstruct large defects. Disadvantages of the LD musculocutaneous flap are requirement of patient repositioning and increasing of the operation time. Superiorities of the RA flap are sufficient bulk of muscle and skin, reliable pedicle anatomy and 2-team work to save time (21-23).

The anterolateral thigh (ALT) flap is considered to be a workhorse flap for reconstruction of maxillary defects. However, the use of ALT flap to repair extensive defects is associated with significant donor site morbidity, but mismatch of the texture and color and in extensive cases insufficient bulk are potential problems.

We prefer to use fVRAM flaps to avoid patient repositioning during operation, and long pedicle of it. If it is the first choice for patients scheduled for later RT, some volume lose can be expected.

In patients with massive defects that expose the base of the skull, construction of a barrier between the oropharyngeal area and the base of the head is essential to prevent bacterial contamination of the brain. Muscle-skin flaps with well-vascularized tissue are ideal in this context; the bulky soft tissue forms a strong barrier supported by the robust blood supply (24).

We did not compare outcomes by defect site or size, because substantial amount of cases were successful. Since all cases were treated with the same type of flap, no statistical analysis was performed. However, our data presented here provided subjective measurements of outcomes, since evaluations were done qualitatively, not quantitatively. We found acceptable support in this study to our initial hypothesis regarding the important aspects of the reconstructive process in terms of oral competence, globe support, obliteration of the defect i.e., palatal reconstruction.

In conclusion, maxillary defects require different levels of skin, soft-tissue, and bone reconstruction, depending on the type of defect. Free tissue transfer is the most effective and reliable method when treating complex defects. The fVRAM flap allows 
reconstruction in three dimensions and is safe and versatile when placed in cases with class IV, V, and VI midfacial defects involving extensive loss of soft tissue.

\section{Ethics}

Informed Consent: This study was approved by the Bezmialem Vakıf University Hospital Institutional Review Board and all participants signed an informed consent agreement.

Peer-review: İnternally and externally peer reviewed.

\section{Authorship Contributions}

Concept: O.K., E.G., İ.M.K., K.Y., Design: O.K., E.G., İ.M.K., K.Y., Data Collection or Processing: O.K., E.G., I.M.K., K.Y., Analysis or Interpretation: O.K., E.G., İ.M.K., K.Y., Literature Search: O.K., E.G., İ.M.K., K.Y., Writing: O.K., E.G., İ.M.K., K.Y.

Conflict of Interest: No conflict of interest was declared by the authors.

Financial Disclosure: The authors declared that this study received no financial support.

\section{References}

1. Cordeiro PG, Disa JJ. Challenges in midface reconstruction. Semin Surg Oncol 2000;19:218-25.

2. Iyer S, Thankappan K. Maxillary reconstruction: Current concepts and controversies. Indian J Plast Surg 2014;47:p.8.

3. Hanasono MM, Silva AK, Yu P, Skoracki RJ. A comprehensive algorithm for oncologic maxillary reconstruction. Plast Reconstr Surg 2013;131:47-60.

4. Brown JS, Shaw RJ. Reconstruction of the maxilla and midface: introducing a new classification. Lancet Oncol 2010;11:1001-8.

5. Cordeiro PG, Chen CM. A 15-year review of midface reconstruction after total and subtotal maxillectomy: part I. Algorithm and outcomes. Plast Reconstr Surg 2012;129:p.124-36.

6. Costa H, Zenha H, Sequeira H, Coelho G, Gomes N, Pinto C, et al. Microsurgical reconstruction of the maxilla: Algorithm and concepts. J Plast Reconstr Aesthet Surg 2015;68:e89-e104.

7. Cordeiro PG, Chen CM. A 15-year review of midface reconstruction after total and subtotal maxillectomy: part II. Technical modifications to maximize aesthetic and functional outcomes. Plast Reconstr Surg 2012;129:139-47.

8. Rodriguez ED, Martin M, Bluebond-Langner R, Khalifeh M, Singh N, Manson PN. Microsurgical reconstruction of posttraumatic high-energy maxillary defects: establishing the effectiveness of early reconstruction. Plast Reconstr Surg 2007;120(7 Suppl 2):103S-17S.

9. Cordeiro PG, Bacilious N, Schantz S, Spiro R. The radial forearm osteocutaneous" sandwich" free flap for reconstruction of the bilateral subtotal maxillectomy defect. Ann Plast Surg 1998;40:397-402.

10. Wei FC, Celik N, Chen HC, Cheng MH, Huang WC. Combined anterolateral thigh flap and vascularized fibula osteoseptocutaneous flap in reconstruction of extensive composite mandibular defects. Plast Reconstr Surg 2002;109:45-52.

11. Wei FC, Seah CS, Tsai YC, Liu SJ, Tsai MS. Fibula osteoseptocutaneous flap for reconstruction of composite mandibular defects. Plast Reconstr Surg 1994;93:294-304; discussion 305-6.

12. Yadav S, Dhupar A, Dhupar V, Akkara F, Mittal HC. Immediate reconstruction of palato-maxillary defect following tumor ablation using temporalis myofascial flap. Natl J Maxillofac Surg 2014;5:2325 .

13. Futran ND, Wadsworth JT, Villaret D, Farwell DG. Midface reconstruction with the fibula free flap. Arch Otolaryngol Head Neck Surg 2002;128:161-6.

14. Andrades P, Rosenthal EL, Carroll WR, Baranano CF, Peters GE. Zygomaticomaxillary buttress reconstruction of midface defects with the osteocutaneous radial forearm free flap. Head Neck 2008;30:1295-302.

15. de la Parra M, Sanchez G, Lopez J, Perez A, Naal N. Total maxillary reconstruction using a double-barreled and double skin paddle fibular flap after total maxillectomy. Arch Plast Surg 2013;40:779-82

16. Zhang L, Sun H, Yu HB, Yuan H, Shen GF, Wang XD. Computer-assisted orthognathic surgery combined with fibular osteomyocutaneous flap reconstruction to correct facial asymmetry and maxillary defects secondary to maxillectomy in childhood. J Craniofac Surg 2013;24:886-9.

17. Grinsell D, Catto-Smith HE. Modifications of the deep circumflex iliac artery free flap for reconstruction of the maxilla. J Plast Reconstr Aesthet Surg 2015;68:1044-53.

18. Valentini V, Gennaro P, Torroni A, Longo G, Aboh IV, Cassoni A, et al. Scapula free flap for complex maxillofacial reconstruction. J Craniofac Surg 2009;20:1125-31.

19. Chen HC, Demirkan F, Wei FC, Cheng SL, Cheng MH, Chen IH. Free fibula osteoseptocutaneous-pedicled pectoralis major myocutaneous flap combination in reconstruction of extensive composite mandibular defects. Plast Reconstr Surg 1999;103:83945.

20. Baumann DP, Yu P, Hanasono MM, Skoracki RJ. Free flap reconstruction of osteoradionecrosis of the mandible: A 10-year review and defect classification. Head Neck 2011;33:800-7.

21. IJsselstein CB, Hovius SE, ten Have BL, Wijthoff SJ, Sonneveld GJ, Meeuwis CA, et al. Is the pectoralis myocutaneous flap in intraoral and oropharyngeal reconstruction outdated? Am J Surg 1996;172:259-62.

22. Barton FE Jr, Spicer TE, Byrd HS. Head and neck reconstruction with the latissimus dorsi myocutaneous flap: anatomic observations and report of 60 cases. Plast Reconstr Surg 1983;71:199-204.

23. Guler MM, Turegun M, Acikel C. Three-dimensional reconstruction of types IV and $\mathrm{V}$ midfacial defects by free rectus abdominis myocutaneous (RAM) flap. Microsurg 1998;18:148-51.

24. Cordeiro PG, Santamaria E. The extended, pedicled rectus abdominis free tissue transfer for head and neck reconstruction. Ann Plast Surg 1997;39:53-9. 